Supporting Information for

\title{
Ionically cross-linked polymers as asymmetric gel polymer electrolytes for enhanced cycle performance of lithium-sulfur batteries
}

\author{
Tsung-Chieh Kuo, ${ }^{a}$ Jen-Chun Hsueh, ${ }^{a}$ Chun-Yu Chiou, ${ }^{a}$ Chi-Hung Su, ${ }^{b}$ and Jyh-Tsung Lee*a,c \\ ${ }^{a}$ Department of Chemistry, National Sun Yat-sen University, Kaohsiung 80424, Taiwan \\ ${ }^{b}$ Cyntec Co, Hsinchu 30076, Taiwan. \\ ${ }^{c}$ Department of Medicinal and Applied Chemistry, Kaohsiung Medical University, Kaohsiung \\ 80708, Taiwan \\ *Corresponding author \\ E-mail:jtlee@faculty.nsysu.edu.tw
}

\section{Contents}

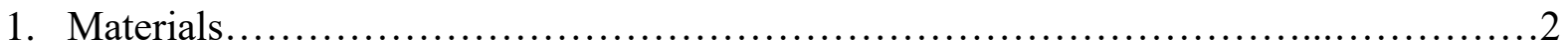

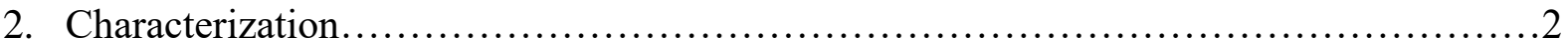

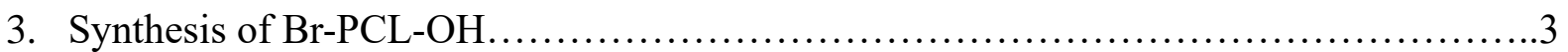

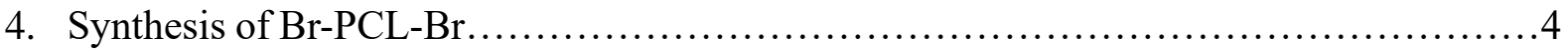

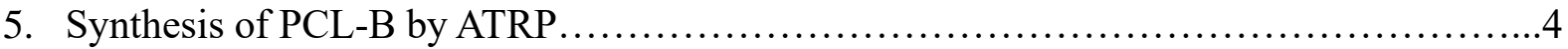

6. Synthesis of poly(BM)-co-PCL-co-poly(BM) .................................. 5

7. Synthesis of PMAA-co-PCL-co-PMAA (PCL-A) ....................................

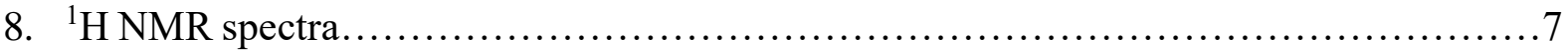

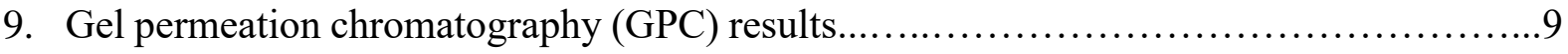

10. Thermal gravimetric analysis (TGA) ............................................

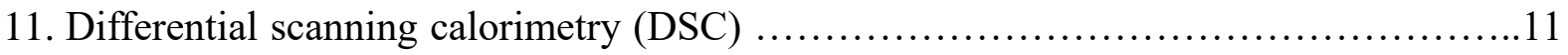

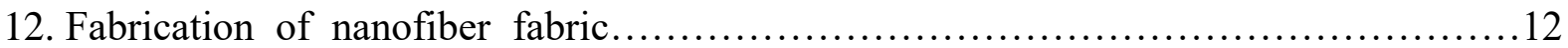

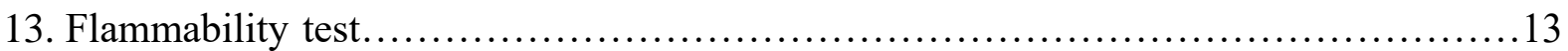

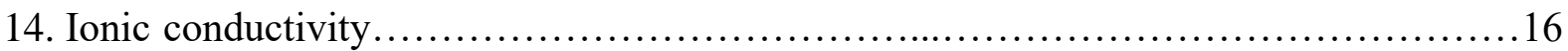

15. Adhesion test of glass slide-polymer after immersed in the electrolyte.................. 17

16. Fabrication of sulfur electrodes.................................................... 17

17. PCL-A and PCL-B electrospun on sulfur electrodes................................ 18

18. In situ cross-linking of PCL-A/PCL-B on sulfur electrode by hot pressing................18

19. Electrochemical measurements................................................ 19

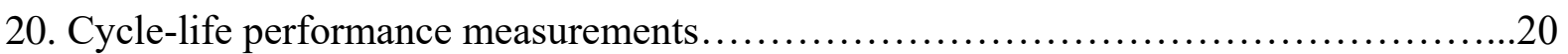

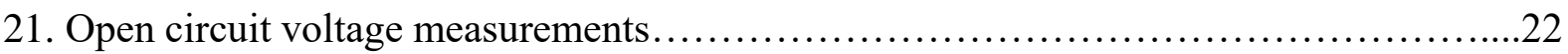

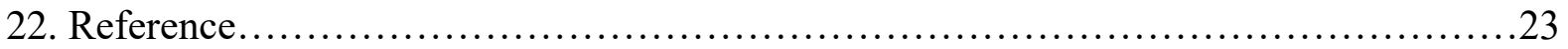




\section{Materials}

$\varepsilon$-Caprolactone (99\%, Alfa Aesar), tin(II) 2-ethylhexanoate (95\%, Sigma-Aldrich), anhydrous magnesium sulfate (99\%, SHOWA), silica gel (particle size $=45-75 \mu \mathrm{m}$, TCI), 4(dimethyloamino)pyridine (DMAP, 99+\%, Alfa Aesar), triethylamine (TEA, >99.5, SigmaAldrich), $\alpha$-bromoisobutyryl bromide (98\%, Alfa Aesar), 2-(dimethylamino)ethyl methacrylate (DMAEMA, 98\%, Sigma-Aldrich), tert-butyl methacrylate (98\%, SigmaAldrich), copper(I) bromide $\quad(98 \%, \quad$ Sigma-Aldrich), $\quad 1,1,4,7,10,10-$ hexamethyltriethylenetetramine (HMTETA , 97\%, Sigma-Aldrich), trifluoroacetic acid (TFA, 99\%, Alfa Aesar), aluminum oxide (Merck), tetrahydrofuran (THF, HPLC grade, Duksan), dichloromethane (99.5\%, Duksan), methanol (99.5\%, Macron), hexane (99\%, Macron), toluene (100\%, Merck), chloroform-d (99.8\%, Sigma-Aldrich), Super P (Timcal), KS-6 (Timcal), polyvinylidene difluoride (PVDF, KF-1100, Kureha), tetrahydrofuran (THF, HPLC grade, Duksan), $N$-methyl-2-pyrrolidone (NMP, 99\%, Jassen), polypropylene (PP) separator (Celgard 2500), carbon paper (HCP030N, Shang Hai Chu Xi Industrial Co., Ltd), lithium metal (UBIQ Technology Co., Ltd.), Lithium bis(trifluoromethanesulfonyl)imide (LiTFSI, 99.95\%, Sigma-Aldrich), and 1,2-dimethoxyethane (DME, $99 \%$, Alfa Aesar), and 1,3-dioxolane (DOL, 99.5\%, Alfa Aesar) were used as received.

\section{Characterization}

Infrared spectra in the frequency range of $4000-400 \mathrm{~cm}^{-1}$ were obtained on a PerkinElmer Spectrum Two L1600107 spectrometer with a universal attenuated total reflectance accessory. The ${ }^{1} \mathrm{H}$ nuclear magnetic resonance (NMR) spectra were obtained on a Varian UNITY INOVA-500 spectrometer at $500 \mathrm{MHz}$. Scanning electron microscopy (SEM) images were observed on a high-resolution analytical microscope (Zeiss Supra 55). Thermogravimetric analysis (TGA) was performed with a PerkinElmer TGA 400 instrument, under a $\mathrm{N}_{2}$ 
atmosphere, at a heating rate of $10{ }^{\circ} \mathrm{C} \mathrm{min}^{-1}$ from room temperature to $800{ }^{\circ} \mathrm{C}$. The differential scanning calorimetry (DSC) study was carried out on a differential scanning calorimeter (DSC4000 PerkinElmer) in a $\mathrm{N}_{2}$ atmosphere from $-30{ }^{\circ} \mathrm{C}$ to $100{ }^{\circ} \mathrm{C}$ with a heating rate of $10{ }^{\circ} \mathrm{C}$ $\min ^{-1}$. The cyclic voltammetry (CV) and electrochemical impedance spectroscopy (EIS) were measured on a $\mathrm{CH}$ Instruments (CHI-Model 750A). The specific energy capacity, C-rate, and cycle-life performance of the batteries were measured by a battery testing machine (LANHE CT2001A). The molecular weights of polymers were measured by a gel permeation chromatography (GPC) instrument (Jasco) equipped with a PU-2800 pump, a RI-2031 Plus detector, and a Waters Styragel HR4 column, using THF as an eluent at $45^{\circ} \mathrm{C}$.

\section{Synthesis of Br-PCL-OH}<smiles>O=C1CCCCCO1</smiles>

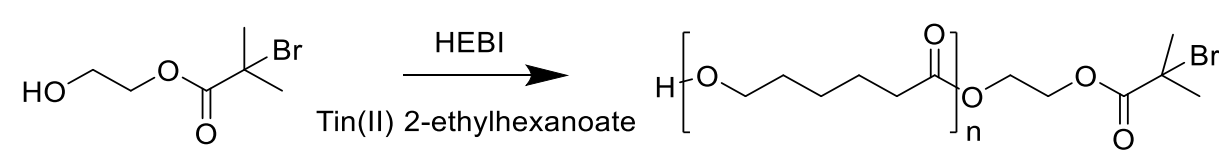

$\varepsilon$-Caprolactone $(85 \mathrm{~mL}, 0.75 \mathrm{~mol}), 2$-hydroxyethyl 2-bromoisobutyrate (synthesized by ethylene glycol and $\alpha$-bromoisobutyryl bromide $)^{1}(20 \mu \mathrm{L}, 0.13 \mathrm{mmol})$, and dried THF $(60 \mathrm{~mL})$ were mixed in a 250 -mL flask. The solution was stirred for 30 minutes to give a homogeneous solution. Tin(II) 2-ethylhexanoate $(1.25 \mathrm{~g}, 3.1 \mathrm{mmol})$ was added to another 250 -mL flask in a glovebox with an argon atmosphere. The homogeneous solution was transferred into the tin(II) 2-ethylhexanoate flask. Then, the solution was heated at $65^{\circ} \mathrm{C}$ for $45 \mathrm{~h}$. After polymerization, the solution gradually became viscous. The viscous solution was cooled down to ambient temperature, and then precipitated in excess cold methanol $\left(1000 \mathrm{~mL}, 4^{\circ} \mathrm{C}\right)$ to get a white solid polymer, $\alpha$-bromo- $\omega$-hydroxy-PCL, Br-PCL-OH, and then the solid polymer was collected by filtration. The polymer was re-dissolved in THF and precipitated in excess cold methanol three times to purify the polymer. After the purification, the polymer was dried under vacuum at 
ambient temperature (yield: 76\%). The polymer was characterized by NMR spectroscopy and GPC.

\section{Synthesis of Br-PCL-Br}<smiles>CC(C)OCCCCCC(=O)OCCOC(=O)C(C)(C)Br</smiles><smiles>CC(C)C(=O)C(C)(Br)Br</smiles><smiles>CC(C)(Br)C(=O)OCCCCCC(=O)OCCOC(=O)C(C)(C)Br</smiles>

Br-PCL-OH (20 g, $0.68 \mathrm{mmol})$ and 4-dimethylaminopyridine (DMAP, $85.5 \mathrm{mg}, 0.68 \mathrm{mmol}$ ) were dissolved in a $250-\mathrm{mL}$ flask of THF $(60 \mathrm{~mL})$ at room temperature and stirred for $30 \mathrm{~min}$. After the solids were dissolved completely, triethylamine (TEA, $0.7 \mathrm{mg}, 6.8 \mathrm{mmol}$ ) was added and stirred for $10 \mathrm{~min}$. The reaction flask was placed in a nitrogen atmosphere of box, and then BiB (0.724 mg, $3.06 \mathrm{mmol})$ was slowly added to the flask. When adding, a white solid would gradually precipitate. The solution was stirred for $20 \mathrm{~min}$. The solution was added in excess cold methanol $\left(1000 \mathrm{~mL}, 4^{\circ} \mathrm{C}\right)$ to give a white solid of $\mathrm{Br}-\mathrm{PCL}-\mathrm{Br}$ and then the solid was collected by filtration. The solid was dried under vacuum at ambient temperature (yield: $82 \%$ ).

\section{Synthesis of PCL-B by ATRP}

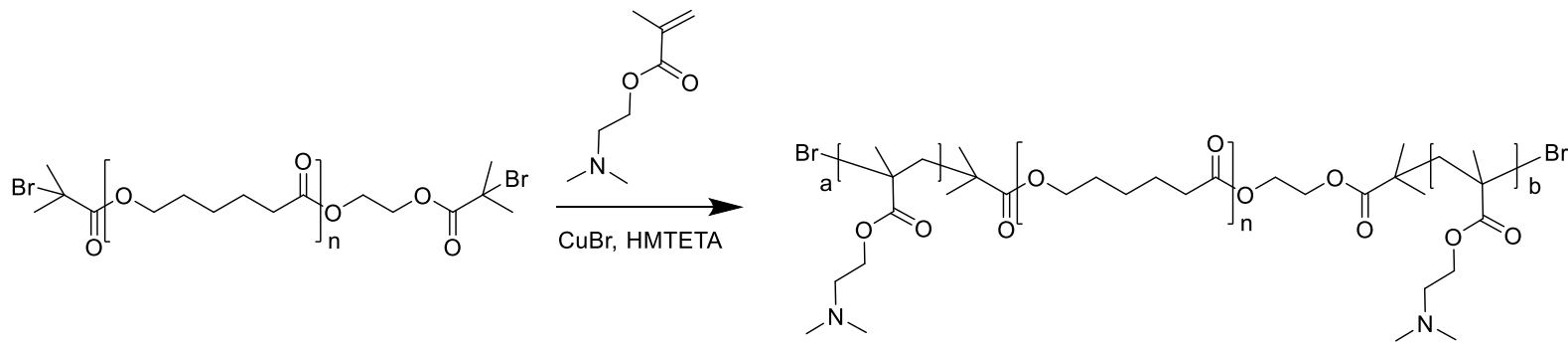

Br-PCL-Br (3 g, $0.1 \mathrm{mmol})$ and DMAEMA $(2.36 \mathrm{~g}, 15 \mathrm{mmol})$ were dissolved in a $125-\mathrm{mL}$ flask of dried toluene $(25 \mathrm{~mL})$, and the solution was stirred until all solids have dissolved. The 
solution was degassed by one freeze-pump-thaw cycle and filled with nitrogen gas. HMTETA (287.9 $\mathrm{mg}, 1.25 \mathrm{mmol}$ ) was added into the flask, and two more freeze-pump-thaw cycles were conducted. The above solution was transferred into another $125-\mathrm{mL}$ flask with $\mathrm{Cu}(\mathrm{I}) \mathrm{Br}$ (46.6 $\mathrm{mg}, 0.325 \mathrm{mmol}$ ) that was taken in an argon-filled glovebox. The flask was heated at $65^{\circ} \mathrm{C}$ for $24 \mathrm{~h}$ under a nitrogen atmosphere to get poly(DMAEMA)-co-PCL-co-poly(PDMAEMA), PCL-B. Upon cooling, the PCL-B polymer was precipitated by pouring the solution into abundant cold $\left(1000 \mathrm{~mL}, 4{ }^{\circ} \mathrm{C}\right)$. The polymer re-dissolved in THF and precipitated in excess cold methanol three times to purify the polymer. Finally, the polymer was dried under vacuum at ambient temperature (yield: 75\%). The PCL-B polymer was characterized by NMR analysis and GPC.

\section{Synthesis of poly(BM)-co-PCL-co-poly(BM)}

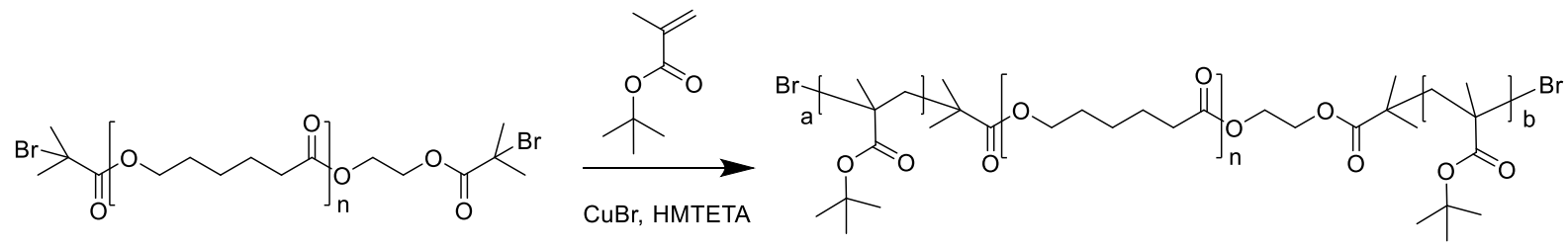

Br-PCL-Br (3 g, $0.1 \mathrm{mmol})$ and tert-butyl methacrylate $(2.133 \mathrm{~g}, 15 \mathrm{mmol})$ were dissolved in a $125-\mathrm{mL}$ flask of dried THF (25 mL). The THF solution was stirred until all solids have dissolved. The flask was degassed by one freeze-pump-thaw cycle and filled with nitrogen gas. HMTETA (287.9 mg, $1.25 \mathrm{mmol}$ ) was added into the flask, and two more freeze-pump-thaw cycles were conducted. The above solution was transferred into another $125-\mathrm{mL}$ flask with $\mathrm{Cu}(\mathrm{I}) \mathrm{Br}(46.6 \mathrm{mg}, 0.325 \mathrm{mmol})$ that was taken under an argon atmosphere from a glovebox. The solution was heated at $65^{\circ} \mathrm{C}$ for $24 \mathrm{~h}$ under nitrogen atmosphere to synthesize poly(BM)co-PCL-co-poly(BM). Upon cooling, the polymer was precipitated by pouring the solution into a large volume of cold hexane $\left(1000 \mathrm{~mL}, 4{ }^{\circ} \mathrm{C}\right)$. The polymer re-dissolved in $\mathrm{THF}$ and 
precipitated in excess cold methanol three times to purify the polymer. Finally, the product was dried under vacuum at ambient temperature (yield: 72\%). The poly(BM)-co-PCL-co-poly(BM), PCL-PA, polymer was characterized by NMR analysis and GPC.

\section{Synthesis of PMAA-co-PCL-co-PMAA (PCL-A)}

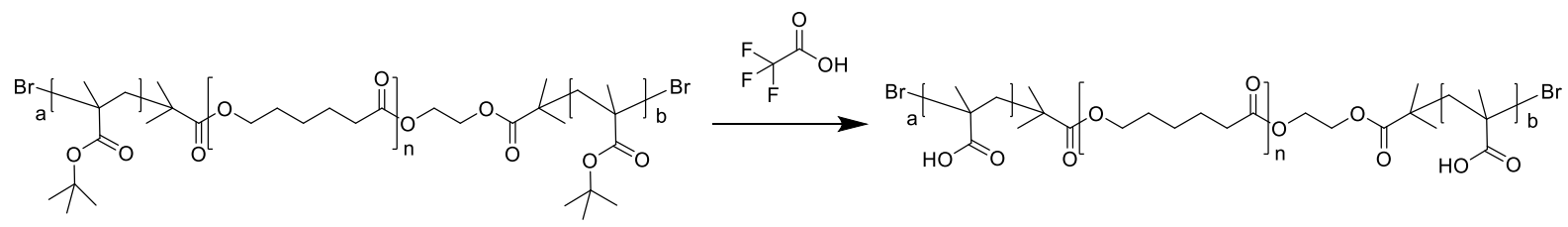

The poly(BM)-co-PCL-co-poly(BM) polymer $(1 \mathrm{~g})$ was dissolved in a $50-\mathrm{mL}$ flask of dried dichloromethane $(10 \mathrm{~mL})$ and then stirred for $30 \mathrm{~min}$. After the polymer was dissolved, the TFA (5 mL, $20 \mathrm{wt}$. in dichloromethane) was added dropwise. The solution was stirred at room temperature for 3 hours and then the solvent and excess TFA were removed by a rotary evaporator at $45^{\circ} \mathrm{C}$ to get poly(methacrylic acid)-co-PCL-co-poly(methacrylic acid), PMAAco-PCL-co-PMAA, denoted as PCL-A. To purify the polymer, the polymer was dissolved in THF and precipitated in excess cold hexane three times. Finally, the polymer was dried under vacuum at ambient temperature (yield: $85 \%$ ). The PCL-A polymer was characterized by NMR analysis and GPC. 


\section{8. ${ }^{1} \mathrm{H}$ NMR spectra}

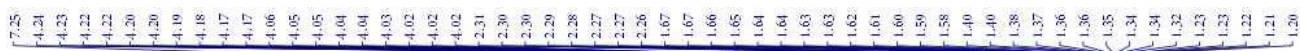<smiles>CC(C)(Br)C(=O)OCCCCCC(=O)OCCOC(=O)C(C)(C)Br</smiles>

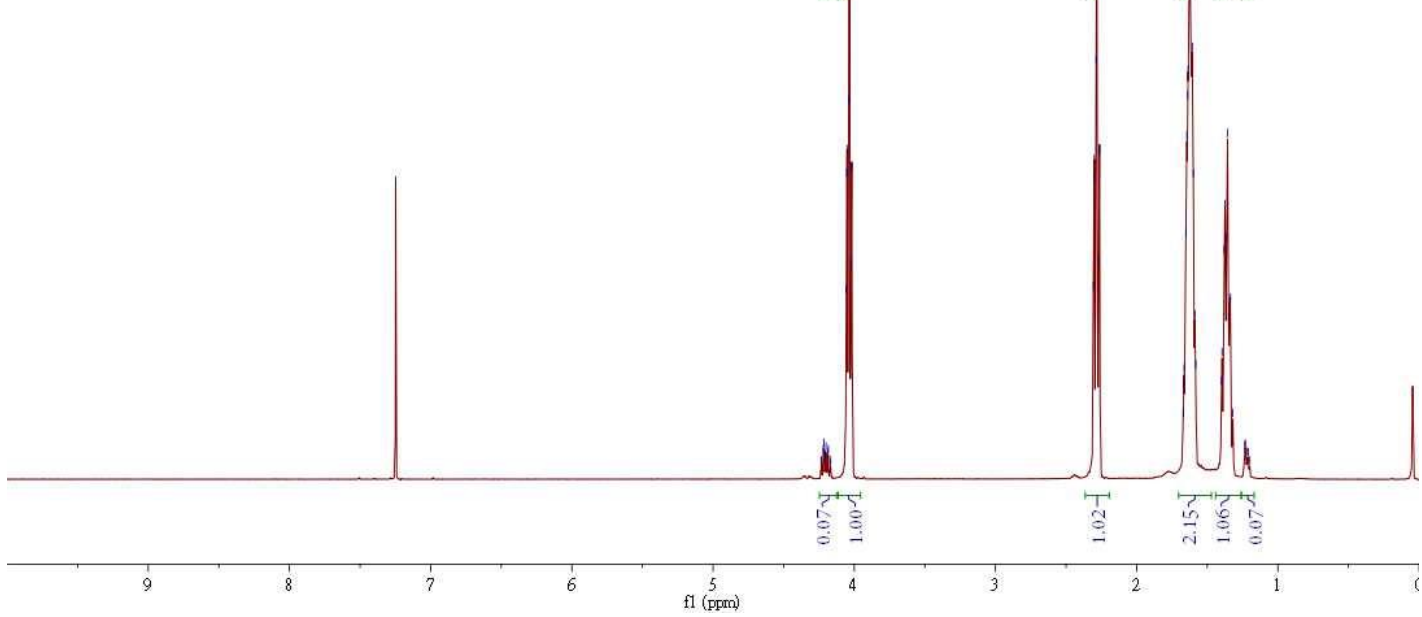

Figure S1. ${ }^{1} \mathrm{H}$ NMR spectrum of Br-PCL-Br.

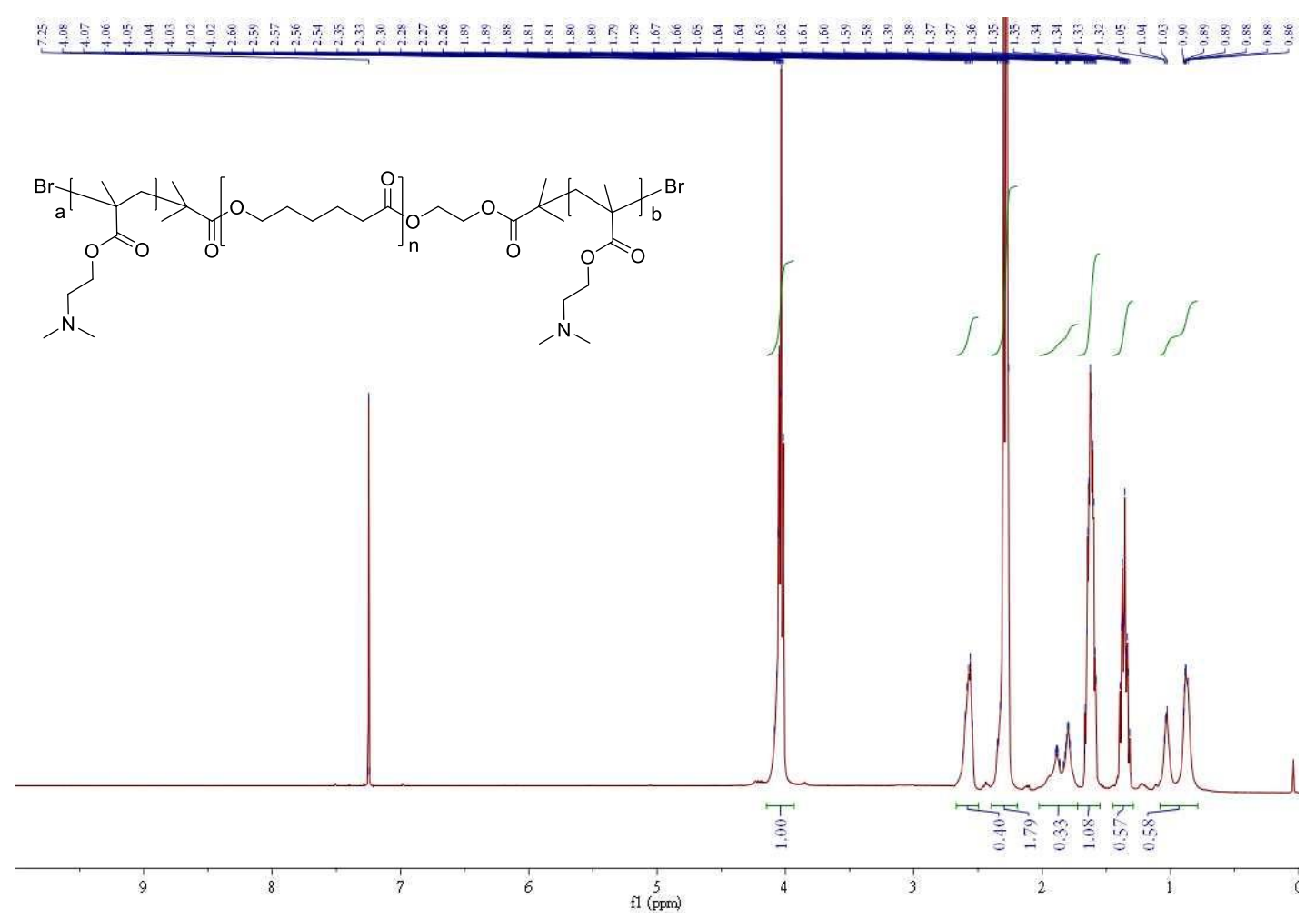

Figure S2. ${ }^{1} \mathrm{H}$ NMR spectrum of poly(DMAEMA)-co-PCL-co-poly(PDMAEMA), PCL-B. 


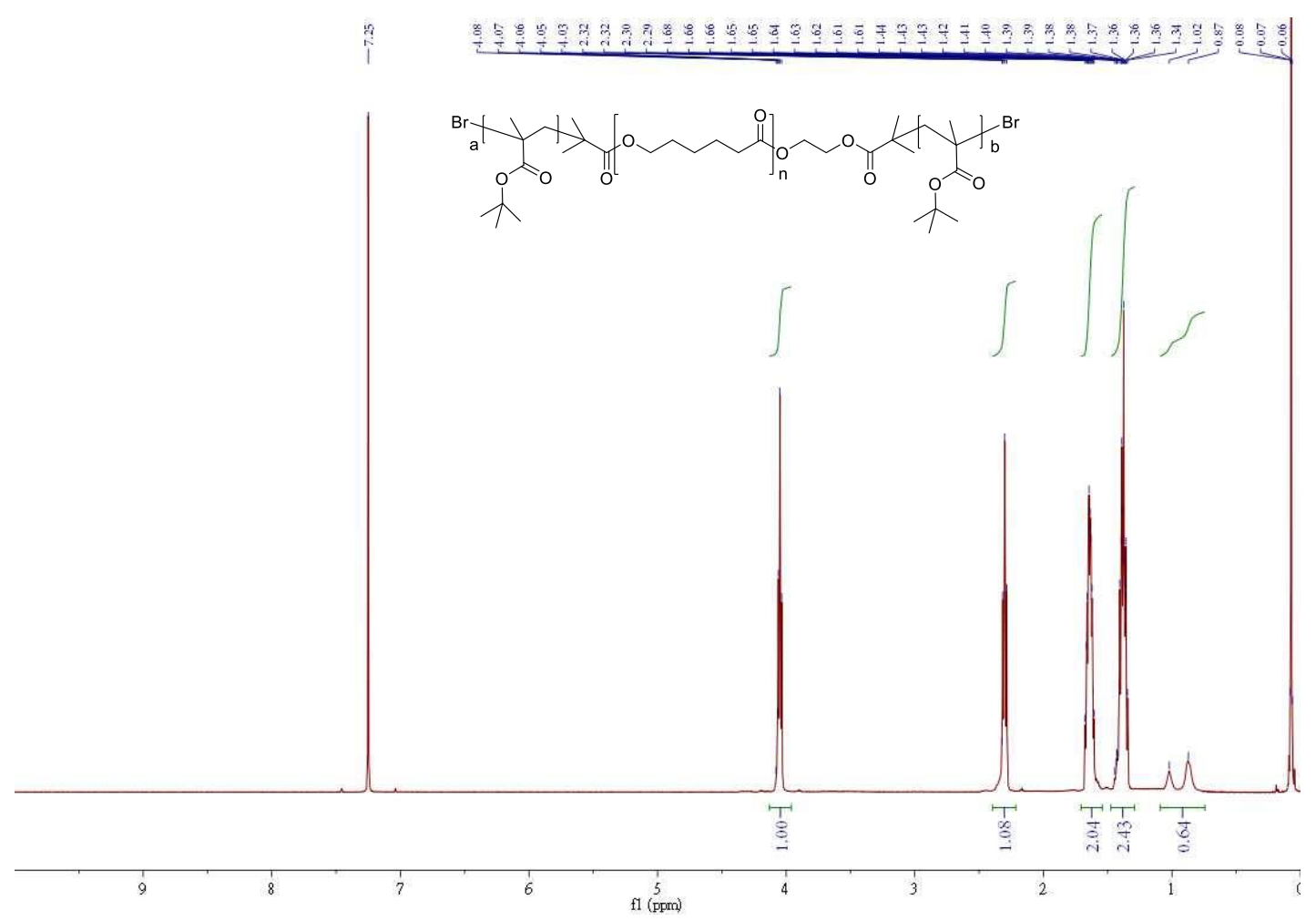

Figure S3. ${ }^{1} \mathrm{H}$ NMR spectrum of poly(BM)-co-PCL-co-poly(BM), PCL-PA.

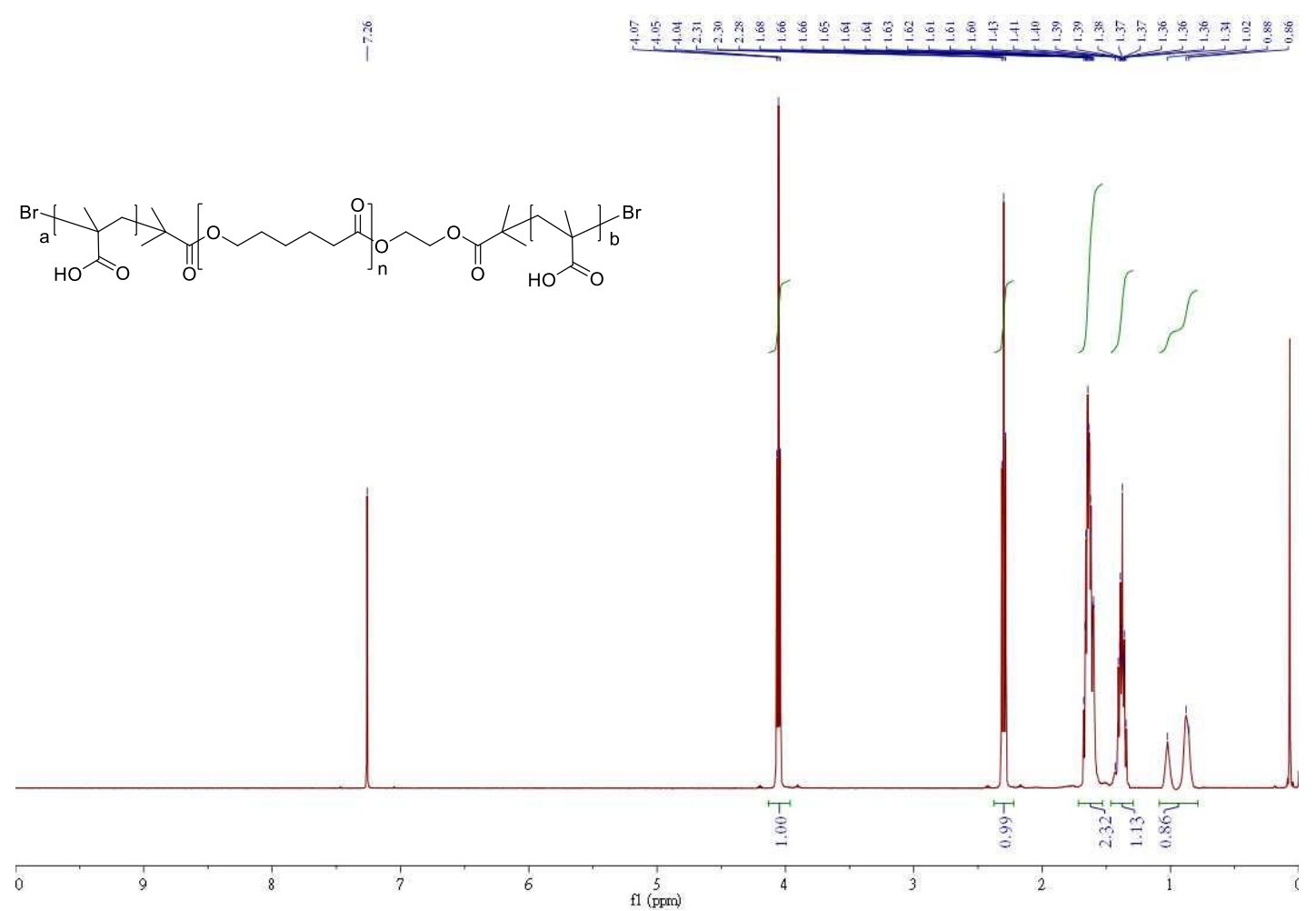

Figure S4. ${ }^{1} \mathrm{H}$ NMR spectrum of PMAA-co-PCL-co-PMAA, PCL-A. 


\section{GPC results}

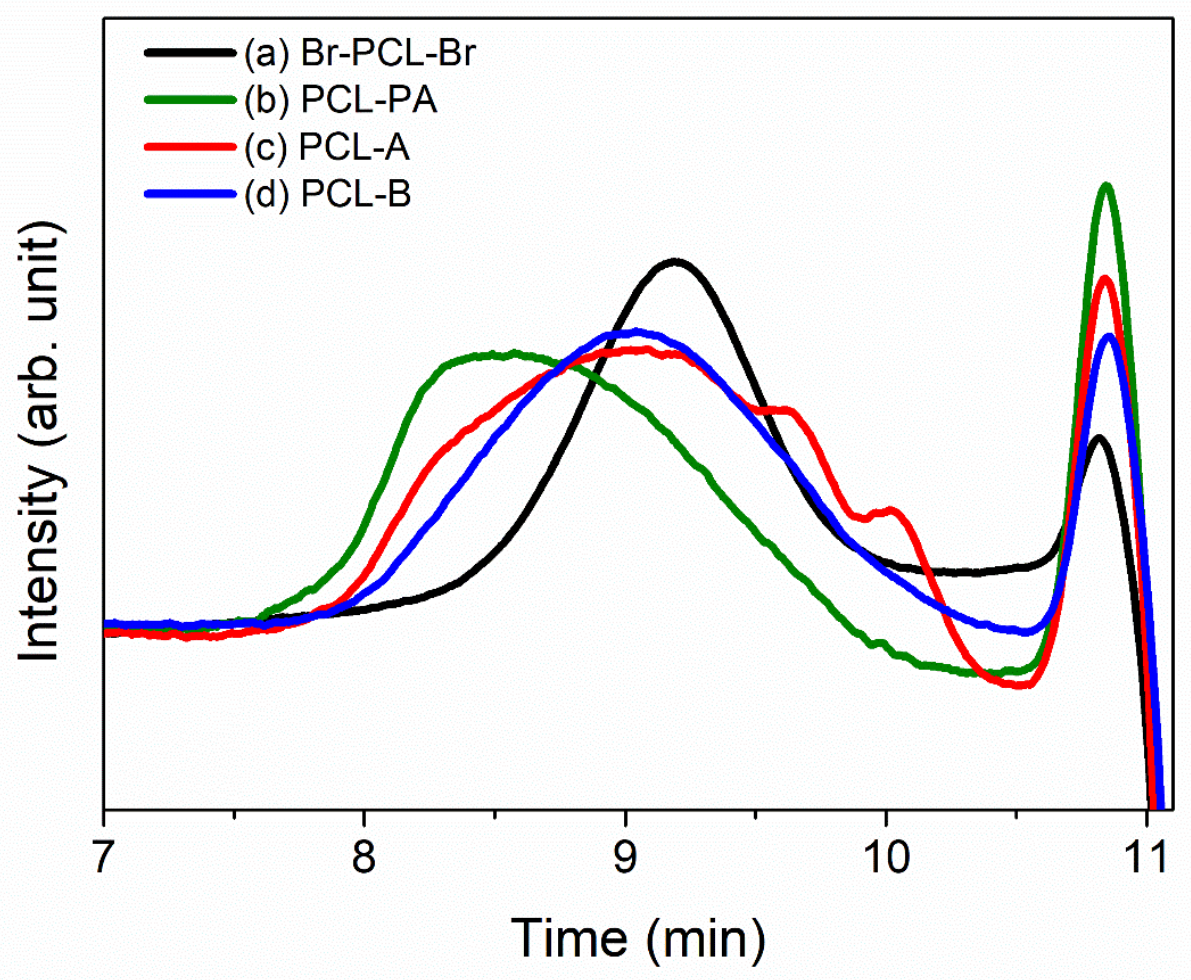

Figure S5. GPC curves of (a) Br-PCL-Br, (b) PCL-PA, (c) PCL-A, and (d) PCL-B.

Table S1 Number average molecular weight $\left(M_{\mathrm{n}}\right)$, weight average molecular weight $\left(M_{\mathrm{w}}\right)$, and polydispersity index (PDI) of polymers.

\begin{tabular}{cccc}
\hline Polymer & $\boldsymbol{M}_{\mathbf{n}}$ & $\boldsymbol{M}_{\mathbf{w}}$ & PDl \\
\hline PCL-Br & 24,200 & 30,300 & 1.25 \\
PCL-PA & 28,600 & 43,800 & 1.53 \\
PCL-A & 26,500 & 48,100 & 1.82 \\
PCL-B & 26,900 & 47,000 & 1.75 \\
\hline
\end{tabular}


10. Thermal gravimetric analysis (TGA)

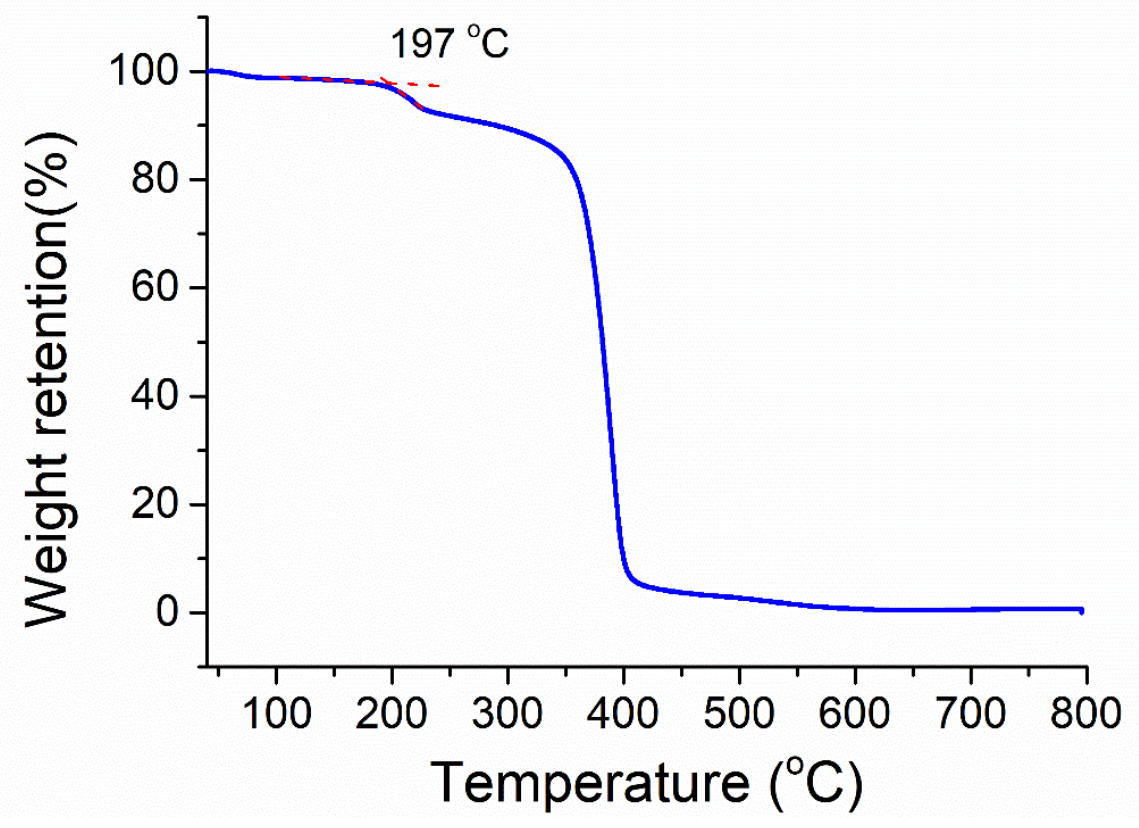

Figure S6. TGA curve of cross-linked PCL-A/PCL-B. 


\section{Differential scanning calorimetry (DSC)}

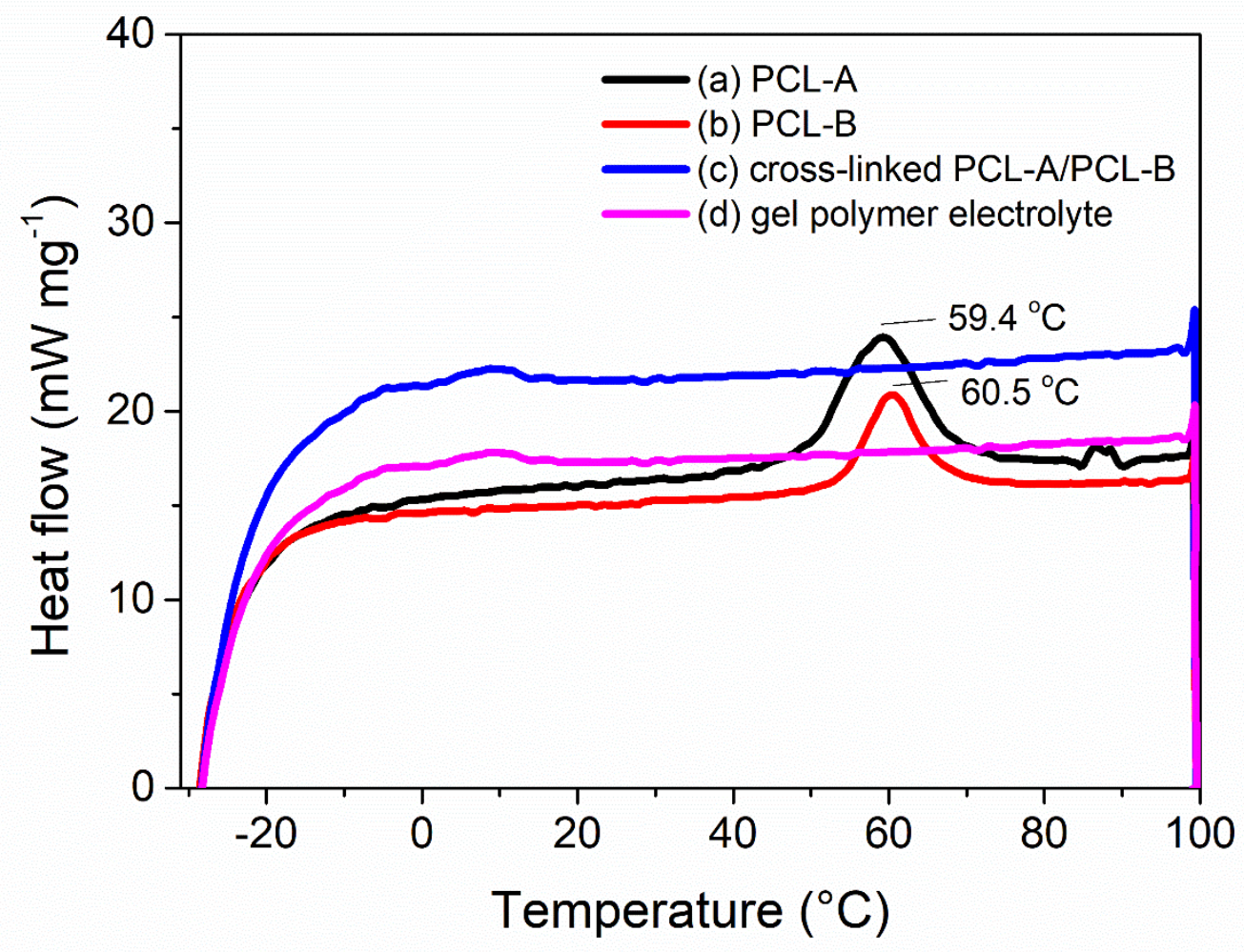

Figure S7. DSC curves of (a) PCL-A, (b) PCL-B, (c) cross-linked PCL-A/PCL-B, and (d) gel polymer electrolyte.

Figure S7 shows the DSC curves of PCL-A, PCL-B, cross-linked PCL-A/PCL-B polymers, and gel polymer electrolyte. Figure S7a and b show an exothermal peak at about $60{ }^{\circ} \mathrm{C}$ in the curves of PCL-A and PCL-B, respectively, which is attributed to the low melting point of the main chain of PCL. Figure S7c and d show that there is no any peak of melting point for thermally cross-linked PCL-A/PCL-B polymers and gel polymer electrolyte, respectively, because the cross-linked polymers have three-dimensional network structures. 


\section{Fabrication of nanofiber fabric}

PCL-A or PCL-B (300 mg) was dissolved in a cosolvent of dichloromethance/ $N, N$ dimethylformide (4/6, v/v) of $0.6 \mathrm{~mL}$. The electrospinning set-up (Figure S8) included a programmable syringe pump (model No. NE-300, New Era, USA), a plastic syringe with a volume of $5 \mathrm{~mL}$ equipped with a stainless steel needle with inner diameter of $0.64 \mathrm{~mm}$ and a length of $20 \mathrm{~mm}$, a high-voltage power supply (model No. MS 3004-PIR 1200, You-Shang Technical Co.). The syringe was filled with $3 \mathrm{~mL}$ of the PCL-A or PCL-B solution and clamped on the syringe pump. The positive terminal of the high voltage supply was clipped with the needle; the negative terminal connected with a metal collector. An Al foil, glass slide, or sulfur electrode was placed on the metal collector. While the applied voltage was set to be $20 \mathrm{kV}$, the solution flow rate was kept $50 \mu \mathrm{L} \min ^{-1}$ for $2 \mathrm{~h}$ to electrospin the nanofiber on the metal collector. Figure S9 shows a free-standing thin film that was electrospun on an $\mathrm{Al}$ foil.

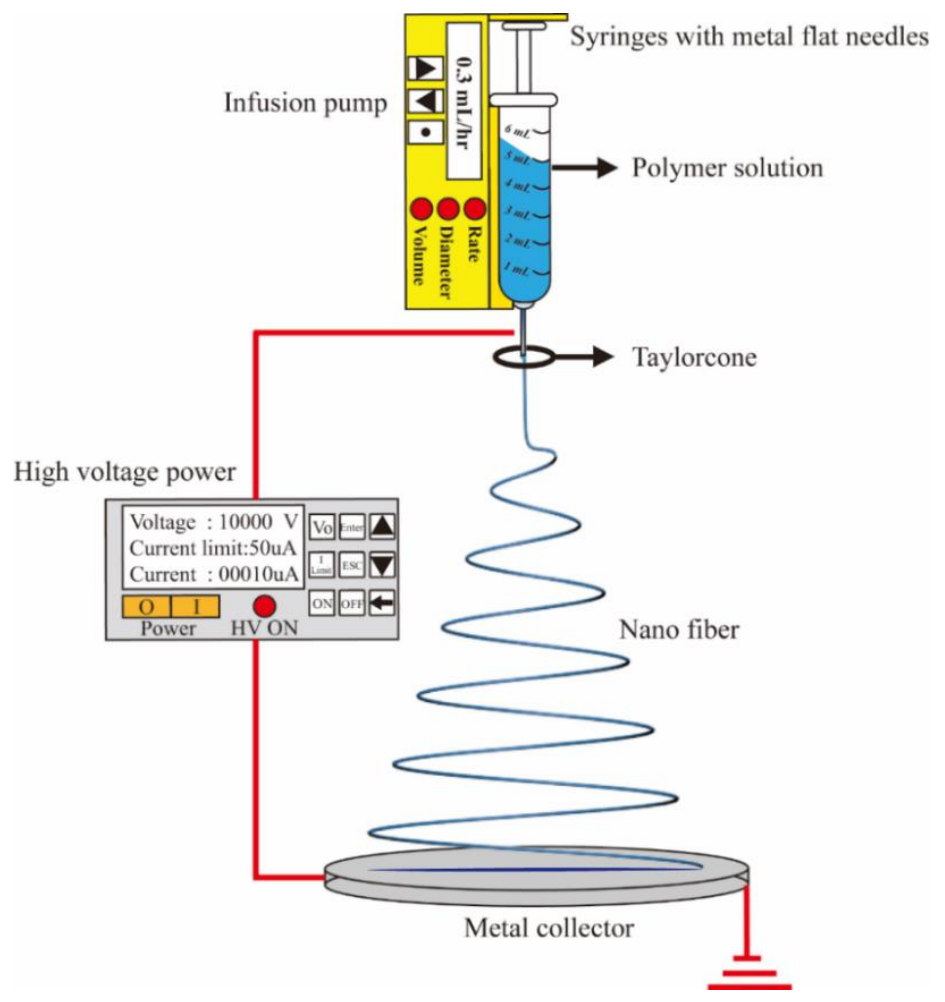

Figure S8. Electrospinning of PCL-A/PCL-B. 


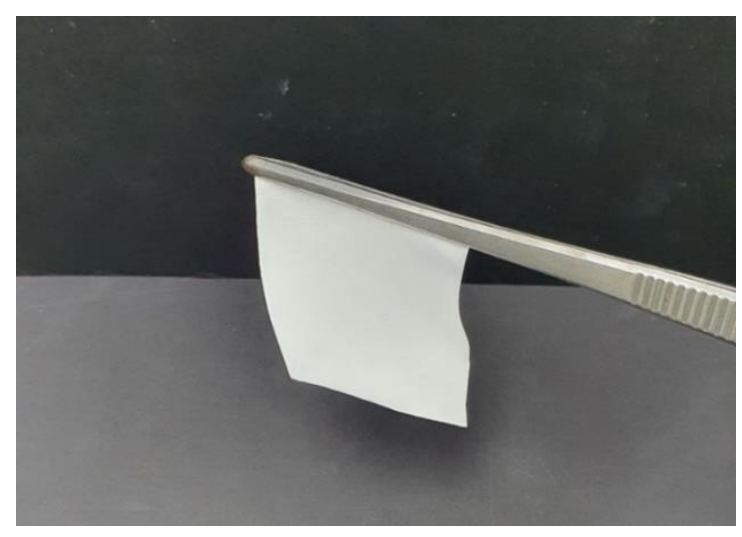

Figure S9. A free-standing thin-film of PCL-A/PCL-B nanofiber.

\section{Adhesion test of glass slide-polymer after immersed in a liquid electrolyte}

PCL-A and PCL-B were sequentially electrospun on microscope a slide $\left(5 \times 2 \mathrm{~cm}^{2}\right)$ by the electrospinning method for 30 minutes to give PCL-A-glass slide, PCL-B-glass slide, and PCL-A/PCL-B-glass slide (Figure S10a). Two polymer-glass sides of two slides were stacked together, which were pressed by applying a weight of $1 \mathrm{~kg}$, and heated at $70{ }^{\circ} \mathrm{C}$ for 10 minutes to form a slide/polymers/slide sandwich structure (Figure S10b). The polymers were melted to take place the cross-linking reaction of acid-base reaction. Then, the slide/polymers/slide sample was immersed in a 1.0 M LiTFSI-DME/DOL $(1 / 1, \mathrm{v} / \mathrm{v})$ with $0.5 \mathrm{M} \mathrm{LiNO}_{3}$ electrolyte for $24 \mathrm{~h}$ for further observation (Figure S10c).

(a)

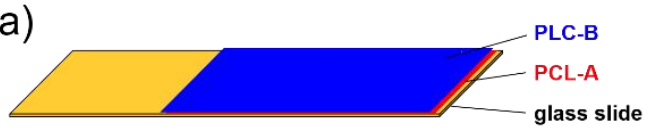

(b)

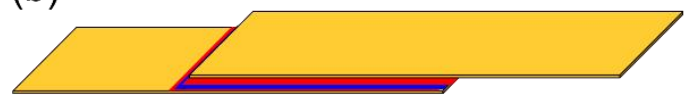

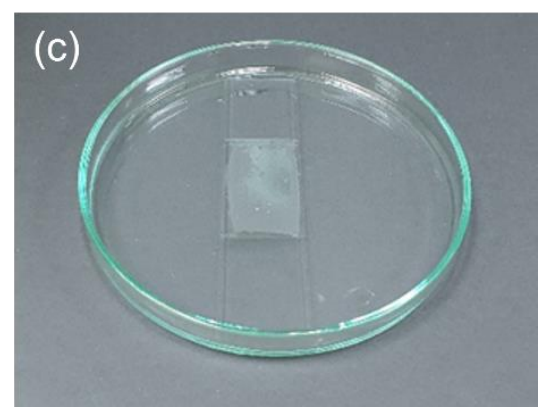

Figure S10. Schematics of the (a) polymer-glass slide and (b) a hot-pressed slide/polymers/slide sandwich structure at $70{ }^{\circ} \mathrm{C}$ for 10 minutes; (c) the hot-pressed sample in a $1.0 \mathrm{M}$ LiTFSI-DME/DOL $(1 / 1, \mathrm{v} / \mathrm{v})$ with $0.5 \mathrm{M}$ $\mathrm{LiNO}_{3}$ electrolyte for $24 \mathrm{~h}$. 
Figure S11a, b, and c show photographs of slide/PCL-A/slide, slide/PCL-B/slide, and slide/PCL-A-PCL-B/slide hot-pressed at $70{ }^{\circ} \mathrm{C}$ after immersed in a 1.0 M LiTFSI-DME/DOL (1/1, v/v) with 0.5 $\mathrm{M} \mathrm{LiNO}_{3}$ electrolyte, respectively. In the cases of either PCL-A or PCL-B, the polymers were completely dissolved and the slides were detached after one hour. By contrast, the cross-linked polymers (PCL-A-PCL-B) are not dissolved in the electrolyte, and the slides are still tightly bound together even after immersed for $24 \mathrm{~h}$. These results indicate that the cross-linked polymer exhibits excellent solvent stability.
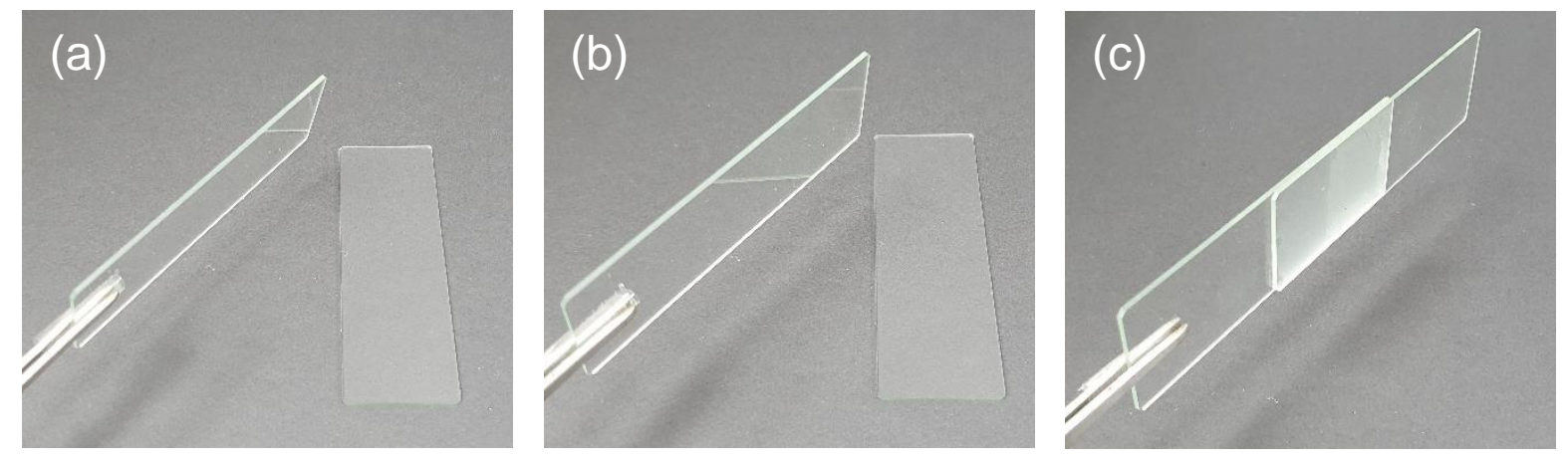

Figure S11. Photographs of hot-pressed (a) slide/PCL-A/slide, (b) slide/PCL-B/slide, and (c) slide/PCL-A-PCL$\mathrm{B} / \mathrm{slide}$ hot-pressed at $70{ }^{\circ} \mathrm{C}$ after immersed in a $1.0 \mathrm{M}$ LiTFSI-DME/DOL $\left(1 / 1\right.$, v/v) with $0.5 \mathrm{M} \mathrm{LiNO}_{3}$ electrolyte for $24 \mathrm{~h}$.

Figure S12a shows the photographs of the slide/PCL-A-PCL-B/slide hot-pressed at 50, 60, 70 , and $80{ }^{\circ} \mathrm{C}$. Since the hot-pressed temperature at $50{ }^{\circ} \mathrm{C}$ does not reach the melting points of the polymers, the color of polymers still remained white. When the hot-pressed temperature was higher than $60{ }^{\circ} \mathrm{C}$, the polymers melted and became transparent (Figure S12a). After the hot-pressed treatment, the samples were immersed in a $1.0 \mathrm{M}$ LiTFSI-DME/DOL (1/1, v/v) with $0.5 \mathrm{M} \mathrm{LiNO}_{3}$ electrolyte for $24 \mathrm{~h}$. The sample hot-pressed at $50{ }^{\circ} \mathrm{C}$ was detached and the polymers were completely dissolved in the electrolyte after immersed in the electrolyte for 24 $\mathrm{h}$ (Figure S12b) because the cross-linking reaction between PCL-A and PCL-B did not happen at $50{ }^{\circ} \mathrm{C}$. Although the sample hot-pressed at $60{ }^{\circ} \mathrm{C}$ did not detach after immersed in the 
electrolyte, the polymer on the edge of the slides was slightly dissolved, which may be due to the degree of cross-linking is not high enough. Furthermore, when the hot-pressed temperature was higher than $70{ }^{\circ} \mathrm{C}$, the samples still remain intact and the polymers do not dissolve in the electrolyte. This is because the polymers are highly cross-linked when the hot-pressed temperature is higher than $70{ }^{\circ} \mathrm{C}$. Therefore, in this study, the hot-pressed temperature is set to be $70{ }^{\circ} \mathrm{C}$.
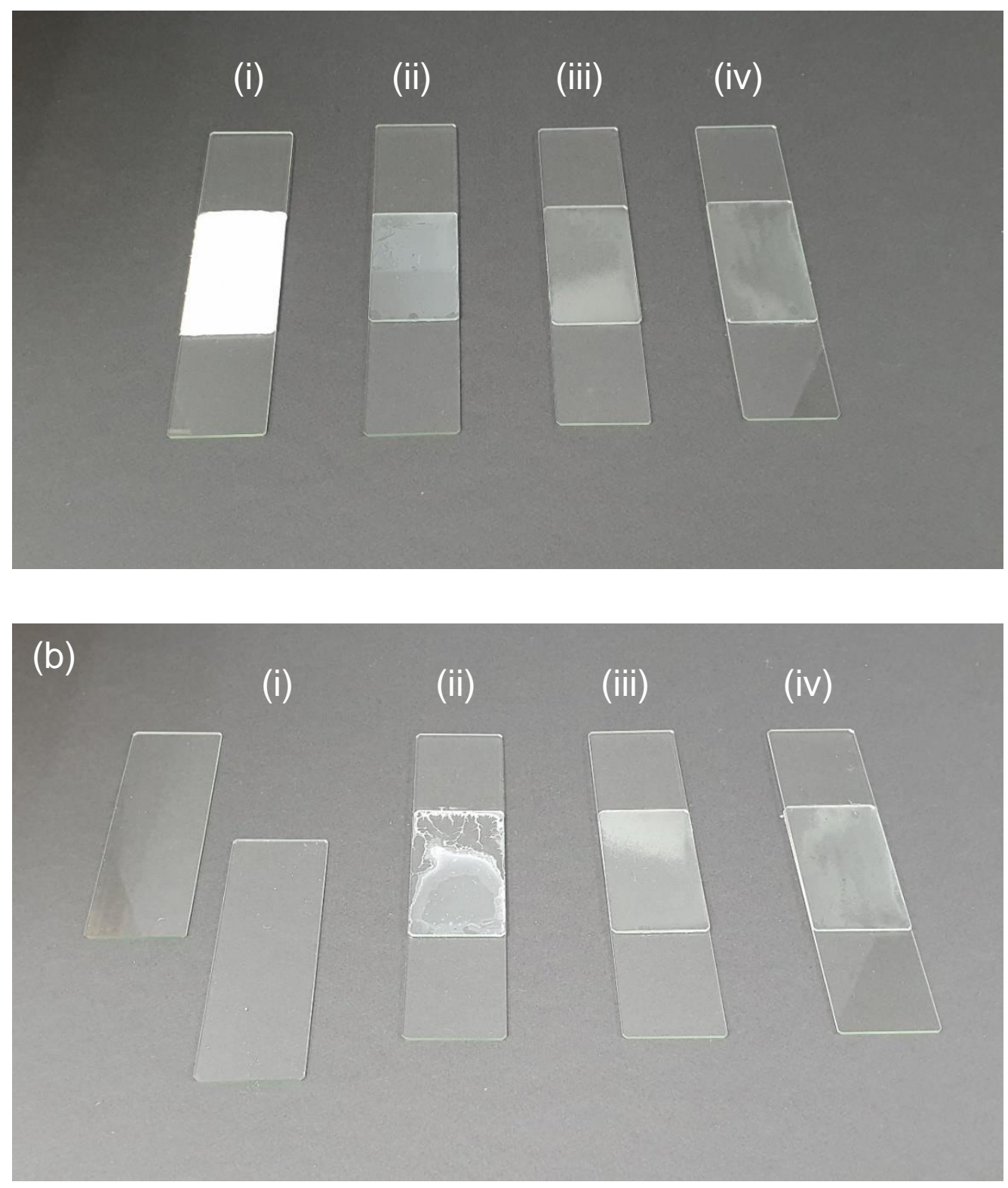

Figure S12. Photographs of (a) the slide/PCL-A-PCL-B/slide hot-pressed at 50, 60, 70, and $80{ }^{\circ} \mathrm{C}$ and (b) the corresponding samples after immersed in a 1.0 M LiTFSI-DME/DOL (1/1, v/v) with $0.5 \mathrm{M} \mathrm{LiNO}_{3}$ electrolyte for $24 \mathrm{~h}$. 


\section{Flammability test}

Figures S13a and b show the photographs of a liquid electrolyte (1.0 M LiTFSI-DME/DOL $(1 / 1, \mathrm{v} / \mathrm{v})$ with $\left.0.5 \mathrm{M} \mathrm{LiNO}_{3}\right)$ and an ionically cross-linked gel polymer electrolyte ignited after moving away from a torch for 3 seconds. Figure S13a shows that the liquid electrolyte is highly flammable. However, the ionically cross-linked gel polymer electrolyte was not ignited, which is non-flammable.
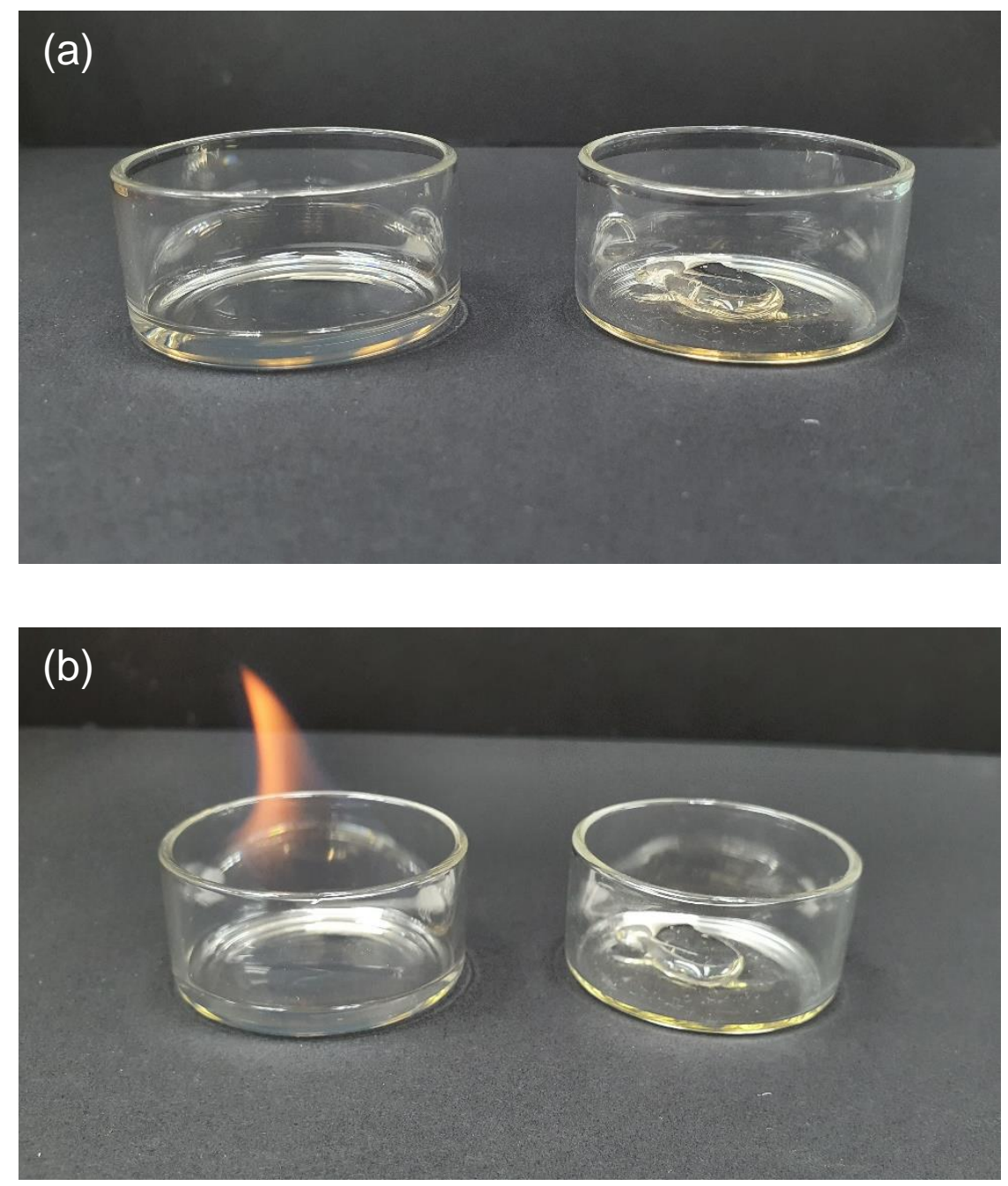

Figure S13. Photographs of flammability tests: a liquid electrolyte (1.0 M LiTFSI-DME/DOL (1/1, v/v) + 0.5 $\mathrm{M} \mathrm{LiNO}_{3}$; left) and an ionically cross-linked gel polymer electrolyte (right) (a) before and (b) after ignition. 


\section{Ionic conductivity}

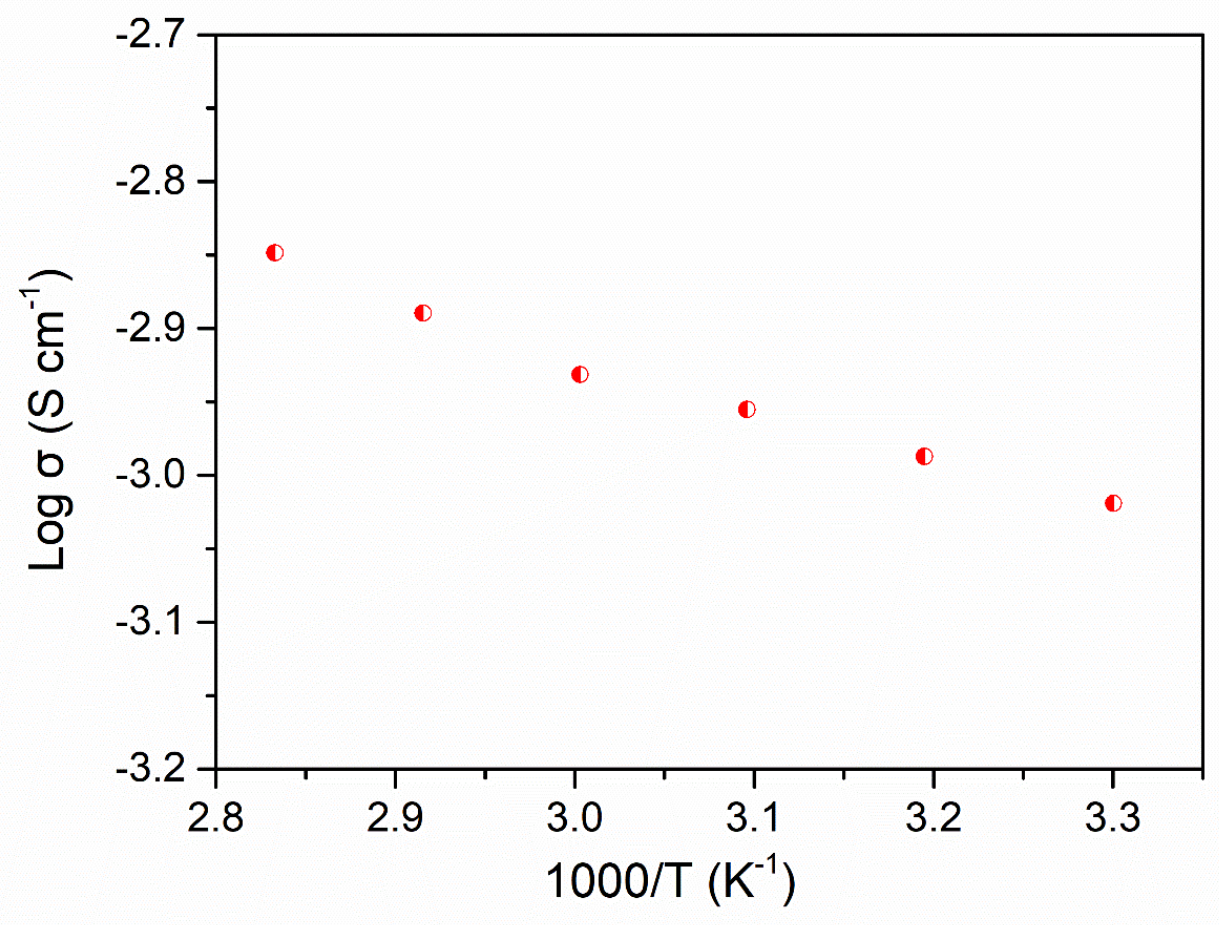

Figure S14. The ionic conductivity as a function of temperature for the gel polymer electrolyte.

\section{Fabrication of sulfur electrodes}

The sulfur cathode consisted of sulfur (350 mg, 70 wt.\%), Super-P carbon (100 mg, 20 wt.\%), and guar gum binder (50 mg, $10 \mathrm{wt} . \%)$. All components were mixed in deionized water $(0.5$ $\mathrm{mL}$ ) and stirred for $6 \mathrm{~h}$ to form a slurry of cathode. The slurry was cast onto a carbon paper and subsequently dried in a vacuum oven at $60{ }^{\circ} \mathrm{C}$ for $12 \mathrm{~h}$. The dried cathode was cut into a circular shape of $13 \mathrm{~mm}$ in diameter and then transferred to a glovebox for storage. The mass loading of sulfur in the electrode was about $0.52 \mathrm{mg} \mathrm{cm}^{-2}$. 


\section{PCL-A and PCL-B electrospun on sulfur electrodes}

PCL-A or PCL-B (300 mg) was dissolved in a co-solvent of dichloromethance/ $N, N$ dimethylformide $(4 / 6, \mathrm{v} / \mathrm{v})$ of $0.6 \mathrm{~mL}$. The electrospinning set-up included a programmable syringe pump (model No. NE-300, New Era, USA), a plastic syringe with a volume of $5 \mathrm{~mL}$ equipped with a stainless steel needle with inner diameter of $0.64 \mathrm{~mm}$ and a length of $20 \mathrm{~mm}$, a high-voltage power supply (model No. MS 3004-PIR 1200, You-Shang Technical Co.). The syringe was filled with $3 \mathrm{~mL}$ of the PCL-A or PCL-B solution and clamped on the syringe pump. The positive terminal of the high voltage supply was clipped with the needle; the negative terminal connected with a sulfur electrode. While the applied voltage was set to be 20 $\mathrm{kV}$, the solution flow rate was kept $50 \mu \mathrm{L} \mathrm{m^{-1 }}$ for $0.5 \mathrm{~h}$. For the PCL-A/PCL-B electrospun on sulfur electrodes, the PCL-A solution (for $0.5 \mathrm{~h}$ ) and the PCL-B solution (for $0.5 \mathrm{~h}$ ) were sequentially electrospun on a sulfur electrode. For the control sample, the polymer solution was PVDF (300 mg) dissolved in a co-solvent of dichloromethance/ $N, N$-dimethylformide $(4 / 6, \mathrm{v} / \mathrm{v})$ of $0.6 \mathrm{~mL}$. All of fabrication conditions are same as the former approach, but the electrospinning time was $1 \mathrm{~h}$.

\section{In situ cross-linking of PCL-A/PCL-B on sulfur electrode by hot pressing}

The PCL-A/PCL-B-electrospun sulfur electrode was hot-pressed with a PP separator by applying a force of $1.0 \mathrm{~kg}$ at $70{ }^{\circ} \mathrm{C}$ for 10 minutes and subsequently transferred to a glovebox for storage for coin-cell assembly. 


\section{Electrochemical measurements}

The PCL-A/PCL-B-electrospin sulfur electrodes were assembled into coin cells (CR 2032) for the CV, EIS, charge-discharge capacity, C-rate, and cycle-life performance measurements. For the CV measurements, the sulfur electrode was used as a working electrode while the counter and reference electrodes consisted of Li metal and PP was employed as a separator. The electrolyte was 1.0 M LiTFSI-DME/DOL (1/1, v/v) with $0.5 \mathrm{M} \mathrm{LiNO}$. The coin cells were assembled in an Ar-filled glovebox. The CV measurements were performed in the voltage window of $1.6-3.0 \mathrm{~V}$ with a scan rate of $0.5 \mathrm{mV} \mathrm{s}^{-1}$. The EIS measurements were conducted on an electrochemical analyzer $(\mathrm{CH}$ Instruments-Model $750 \mathrm{~A})$ at $30^{\circ} \mathrm{C}$. The frequency ranged from $1 \times 10^{5}$ to $0.01 \mathrm{~Hz}$. The coin cells were charged to $3.0 \mathrm{~V}$ and then discharged to $1.6 \mathrm{~V}$ at a constant-current. For measuring the C-rate performance, the cells were charged and discharged at different C-rates $(0.1,0.2,0.5,1$, and $2 \mathrm{C})$ at $30{ }^{\circ} \mathrm{C}$. The cycle-life performance of the coin cells was measured at a charge-discharge rate of $0.5 \mathrm{C}$ at $30^{\circ} \mathrm{C}$. To measure the open circuit voltage of cells, the coin cells were discharged to $1.6 \mathrm{~V}$ and then charge to $3 \mathrm{~V}$ at a C-rate of $0.5 \mathrm{C}$. 


\section{Cycle-life performance measurements}

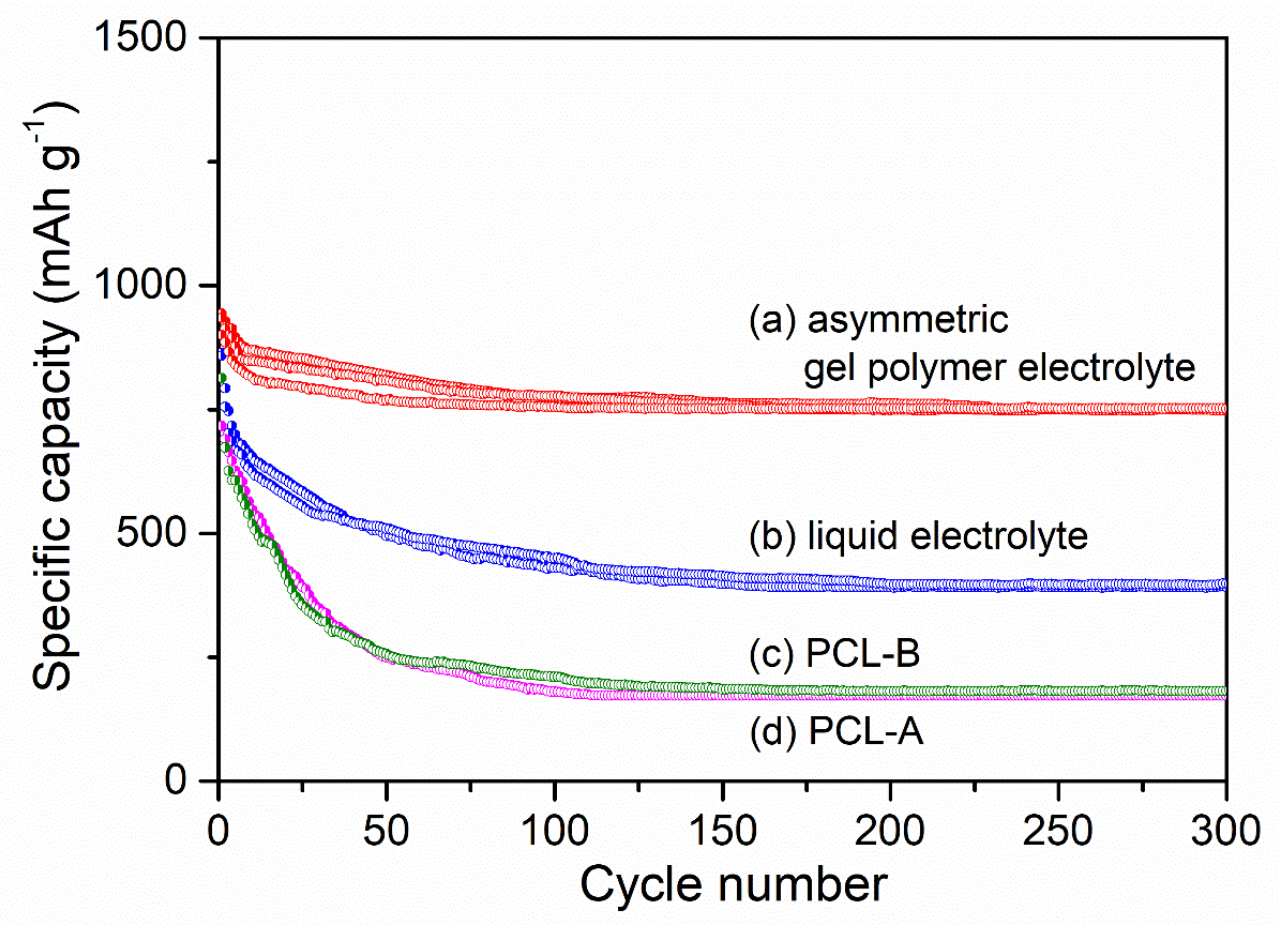

Figure S15. Cycle-life performance of Li || S electrode with (a) an asymmetric gel polymer electrolyte (red; 3 cells), (b) a liquid electrolyte (blue, 2 cells), (c) a PCL-B/liquid electrolyte (green), and (d) a PCL-A/liquid electrolyte (pink) at a charge-discharge rate of $0.5 \mathrm{C}$ at $30^{\circ} \mathrm{C}$.

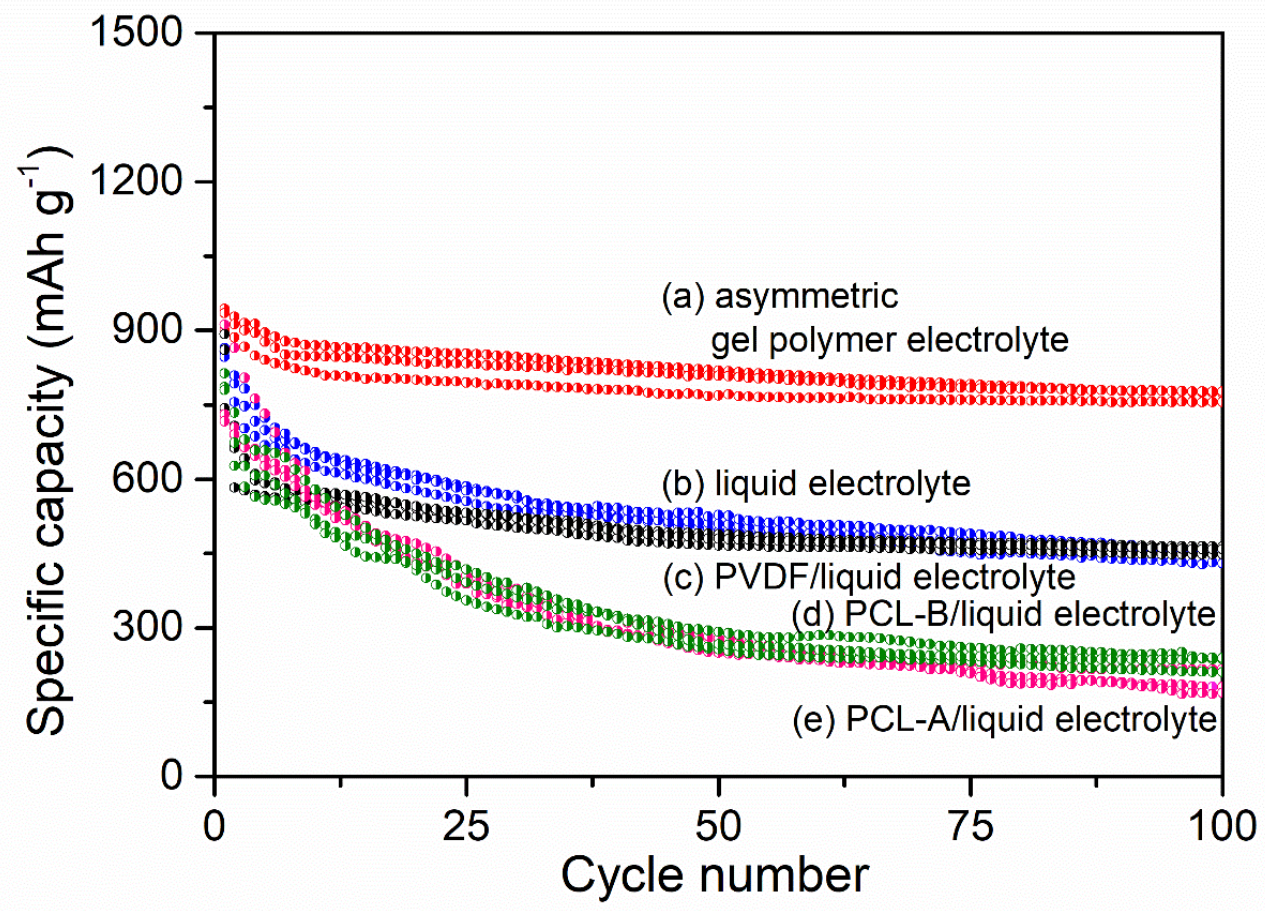

Figure S16. Cycle-life performance of Li || S electrode with (a) an asymmetric gel polymer electrolyte (red; 3 cells), (b) a liquid electrolyte (blue, 3 cells), (c) a PVDF/liquid electrolyte (black, 3 cells), (d) a PCL-B/liquid electrolyte (green, 3 cells), and (d) a PCL-A/liquid electrolyte (pink, cells) at a charge-discharge rate of $0.5 \mathrm{C}$ at $30{ }^{\circ} \mathrm{C}$. 


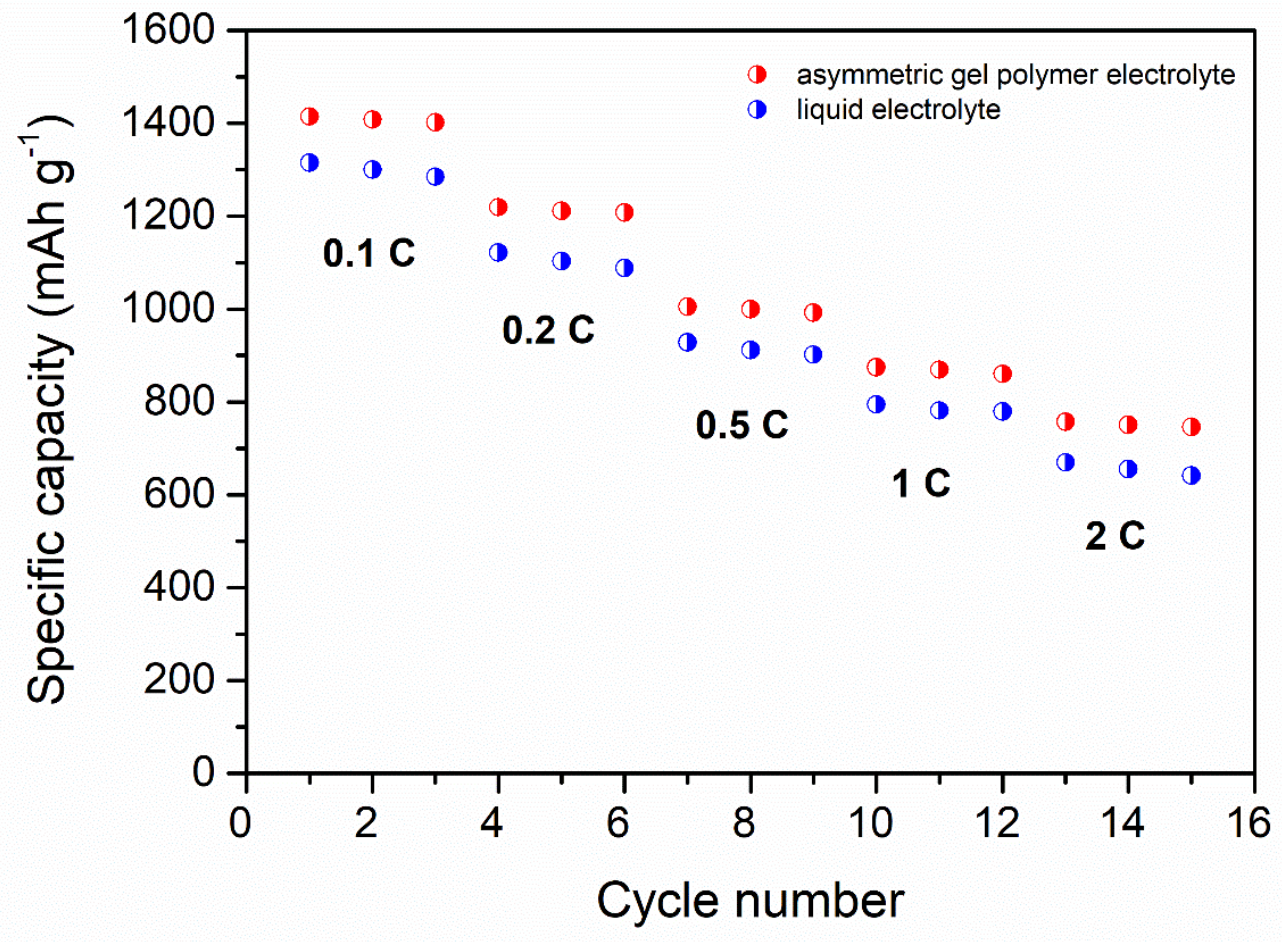

Figure S17. Cycle-life performance of Li || S electrode with an asymmetric gel polymer electrolyte (red) and a liquid electrolyte (blue) at charge-discharge rates of $0.1,0.2,0.5,1$, and $2 \mathrm{C}$ at $30^{\circ} \mathrm{C}$. 


\section{Open circuit voltage measurements}

Figure S17 shows that the cell with the asymmetric gel polymer electrolyte exhibits a lower self-discharge rate.

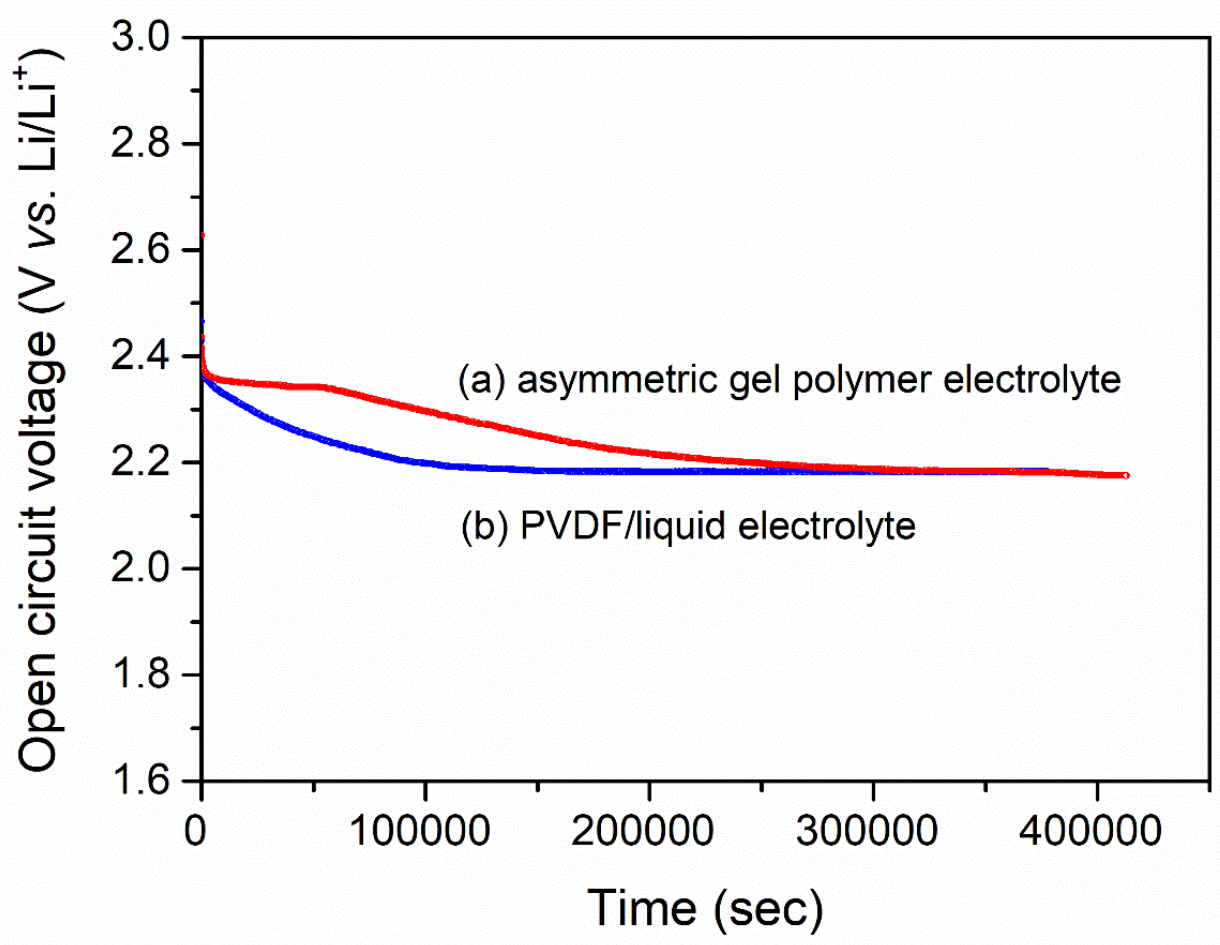

Figure S18. The relationship of the open circuit voltage $v s$. time for Li $\|$ S electrode with (a) an asymmetric gel polymer electrolyte (red) and (b) a PVDF/liquid electrolyte.

Table S1 GPEs for Li-S batteries and their electrochemical performance.

\begin{tabular}{|c|c|c|c|c|}
\hline Polymer & Liquid Electrolyte & $\begin{array}{c}\text { Capacity retention } \\
(\mathrm{mAh} / \mathrm{g} ; \text { cycle })\end{array}$ & $\begin{array}{c}\text { C- rate } \\
\text { (C) }\end{array}$ & Ref. \\
\hline PVDF & $1 \mathrm{M}$ LiTFSI in DME/DOL & $400(100$ th $)$ & 0.2 & 2 \\
\hline PVDF & $\begin{array}{l}1 \mathrm{M} \text { LiTFSI in DME/DOL } \\
\text { with } 0.4 \mathrm{M} \mathrm{LiNO}_{3}\end{array}$ & 484 (300th) & 0.5 & 3 \\
\hline PVDF & $\begin{array}{l}\text { 1.0 M LiTFSI-DME/DOL } \\
(1 / 1, \mathrm{v} / \mathrm{v}) \text { with } 0.5 \mathrm{M} \mathrm{LiNO}_{3}\end{array}$ & 459 (100 th) & 0.5 & this study \\
\hline PCL-A/PCL-B & $\begin{array}{l}\text { 1.0 M LiTFSI-DME/DOL } \\
(1 / 1, \mathrm{v} / \mathrm{v}) \text { with } 0.5 \mathrm{M} \mathrm{LiNO}_{3}\end{array}$ & $\begin{array}{l}778 \text { (100th) } \\
752 \text { (300th) }\end{array}$ & 0.5 & this study \\
\hline- & $\begin{array}{l}\text { 1.0 M LiTFSI-DME/DOL } \\
(1 / 1, \mathrm{v} / \mathrm{v}) \text { with } 0.5 \mathrm{M} \mathrm{LiNO}_{3}\end{array}$ & 293 (300th) & 0.5 & this study \\
\hline PCL-A & $\begin{array}{l}\text { 1.0 M LiTFSI-DME/DOL } \\
(1 / 1, \mathrm{v} / \mathrm{v}) \text { with } 0.5 \mathrm{M} \mathrm{LiNO}_{3}\end{array}$ & $\begin{array}{l}180(100 \text { th }) \\
173(300 \text { th })\end{array}$ & 0.5 & this study \\
\hline PCL-B & $\begin{array}{l}\text { 1.0 M LiTFSI-DME/DOL } \\
(1 / 1, \mathrm{v} / \mathrm{v}) \text { with } 0.5 \mathrm{M} \mathrm{LiNO}_{3}\end{array}$ & $\begin{array}{l}218 \text { (100th) } \\
182 \text { (300th) }\end{array}$ & 0.5 & this study \\
\hline
\end{tabular}




\section{Reference}

1. Cai, J.; Yue, Y.; Rui, D.; Zhang, Y.; Liu, S.; Wu, Chi Macromolecules 2011, 44, 20502057.

2. Sovizi, M. R.; Madram, A. R. Chem. Pap. 2016, 71, 21-28.

3. Shen, Y. Q.; Zeng, F. L.; Zhou, X. Y.; Wang, A. B.; Wang, W. K.; Yuan, N. Y.; Ding, J. N. J. Energy Chem. 2020, 48, 267-276. 